\title{
POST TSUNAMI: MARINE PROTECTED AREAS (MPA) ZONATION STRUCTURE OF PULO ACEH, INDONESIA
}

\author{
PASCA TSUNAMI: STRUKTUR ZONASI DAERAH PERLINDUNGAN LAUT \\ PULO ACEH, INDONESIA
}

\author{
Muhammad Rusdi ${ }^{1)}$, Munawar Khaliil ${ }^{2)}$, Zulfikar $^{2)}$
}

\begin{abstract}
Penelitian ini bertujuan untuk menganalisis pembentukan kawasan perlindungan laut (Marine Protected Areas/MPA) di Pulo Aceh, Indonesia, dengan menggunakan input dari analisis Sistem Informasi Geografis. Langkah-langkah pengelolaan adalah diperlukan untuk memastikan bahwa sumber daya laut dapat hidup dan ekosistem dapat dilestarikan. Fokus penelitian ini adalah untuk menunjuk daerah-daerah tertentu sebagai daerah perlindungan laut (DPL). Pulo Aceh meliputi 24,961.9 hektar yang terdiri dari habitat daratan dan habitat lautan yang terpilih sebagai kawasan MPA. Zonasi di kawasan konservasi laut didasarkan pada data ekologi dan data ekologi konservasi, sosial ekonomi dan budaya masyarakat setempat. Zona utama yang telah ditetapkan dan dipetakan dalam kawasan konservasi, yaitu zona inti (94,14 ha atau 0,38\%), zona pemanfaatan $(15,144.86$ ha atau $60,67 \%)$ dan zona penyangga (1,038.77 ha atau 4,16\%). Zona inti sangat dilarang dari kegiatan pengambilan hasil laut, pariwisata dan ekonomi, sementara kegiatan penelitian dan konservasi dapat diperbolehkan. Zona pemanfaatan dibagi menjadi area untuk pariwisata, penggunaan tradisional, penggunaan pelagis, penelitian dan pelatihan. Akomodasi permanen untuk kegiatan pariwisata atau pengambilan sumber daya alam diperbolehkan melalui pelaksanaan proses penilaian dampak lingkungan terlebih dahulu. Kegiatan di zona penyangga adalah sangat terbatas dan dikendalikan sepenuhnya hanya untuk kegiatan pengambilan hasil laut.
\end{abstract}

Katakunci: Konservasi laut, zonasi, sistem informasi geografis, pemetaan, sumberdaya alam

\section{INTRODUCTION}

Pulo Aceh Archipelagos are consisting of two large islands, Pulo Breuh and Pulo Nasi. Geographically, Pulo Aceh is located on the western coast of Sumatra Island, Administrative located in Pulo Aceh, Aceh Besar district, Aceh Province. Marine and Fisheries Department (2005) released various data that tsunami impact in Aceh Besar district about marine and fisheries infrastructure, and was estimated approximately $90 \%$ or 307.140 USD in total value. Fishing vessels and fishing gear in Aceh Besar district reached $100 \%$ or more than 2.100.000 USD. Pulo Aceh sub district was one of the most destructive areas hit by tsunami. Approximately $100 \%$ of marine and fisheries infrastructure was totally damaged. Total damage was also observed in residential areas which were generally located on the outskirts of the coastal area.

The tsunami had also caused changes on coastal ecology. Changing of shorelines and habitats of organism has been observed in particular areas.
These conditions need specific management and development planning. In another term, the prone areas to natural disasters are requiring anticipatory management of development planning to disaster.

Managing a large area needs the to the development of technology. One of the commonly used technologies is Geographic Information System (GIS). In broad outline, the experts defined that GIS is a computer system that has the ability to store, recall, update, manipulate, analyze and present all forms of geographic data, or spatially referenced information in accordance with the user (Burrough, 1986 in Barrus, 1996, Jaya, 2002, Prahasta, 2005). Spatial data is associated with the spatial location of the general shape of the map. The users are can analyze the geographic location and specific information related to the location of the individual and can support decision making. Solving problems of location suitability, zoning areas for conservation may be in the analysis, simulation, prediction, and description using GIS.

1) Staf Pengajar Fakultas Pertanian Universitas Syiah Kuala

2) Staf Pengajar Fakultas Pertanian Universitas Malikussaleh 


\section{MATERIALS AND METHOD}

Location of the study was conducted in Pulo Aceh (Figure 1). Preparation of proposal for zoning in the MPA Pulo Aceh was based on ecological baseline and socio-economic baseline studies using GIS (Geographical Information System) (FAO, 1987). Determination of Zoning was followed the reference Law. 5 / 1990 on conservation of biological resources and ecosystems.
The coastal and marine habitat at Pulo Aceh after tsunami was totally damaged. Descriptions of this condition are shown as in Figure 2. Where the whole of Pulo Aceh was scrapped flat by the tidal wave.

Therefore, Munthadar, (2008) had reported the existing condition of coral reefs after tsunami as shown in Figure 2. The Figures 3 and 4 show the recruitment of corals on the reef.

\section{RESULTS AND DISCUSSION}

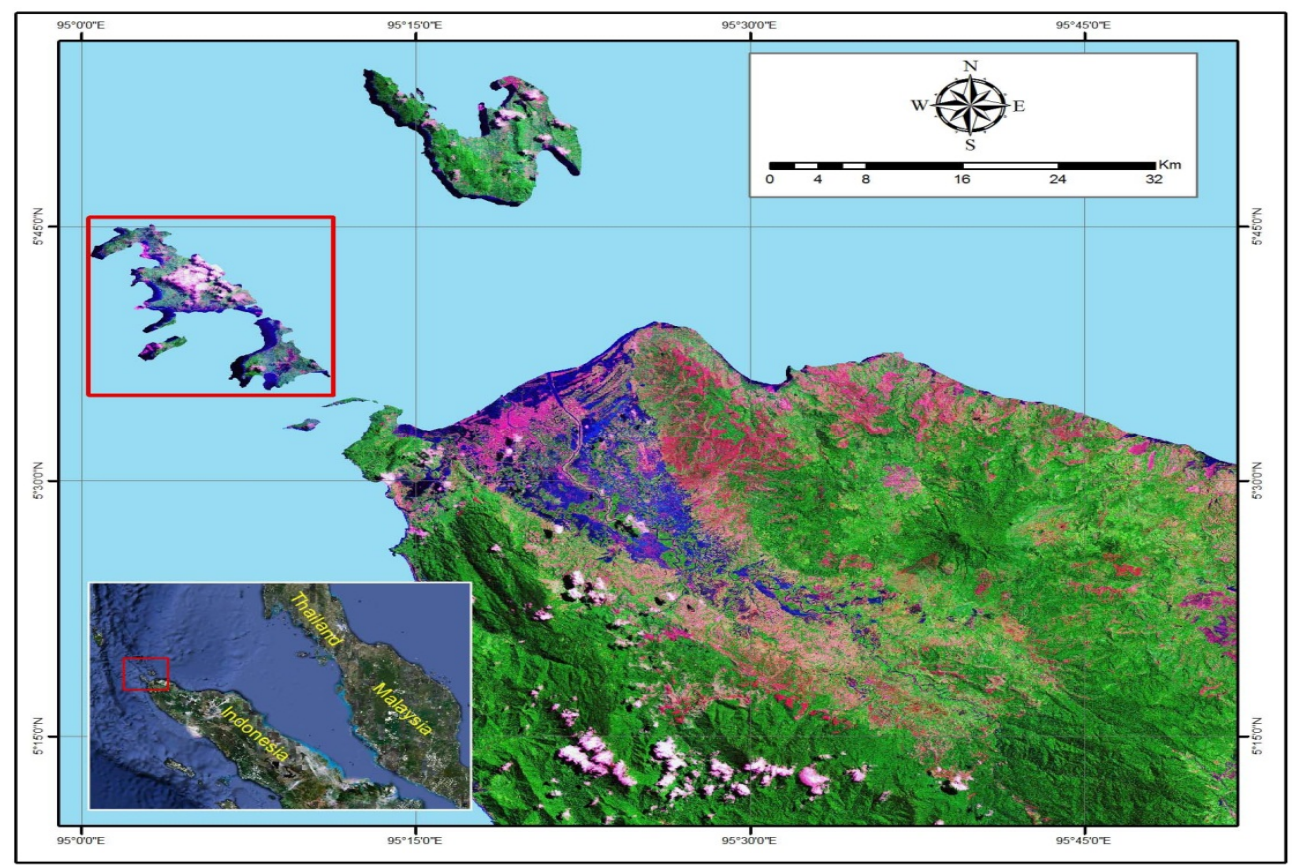

Figure 1. Research location

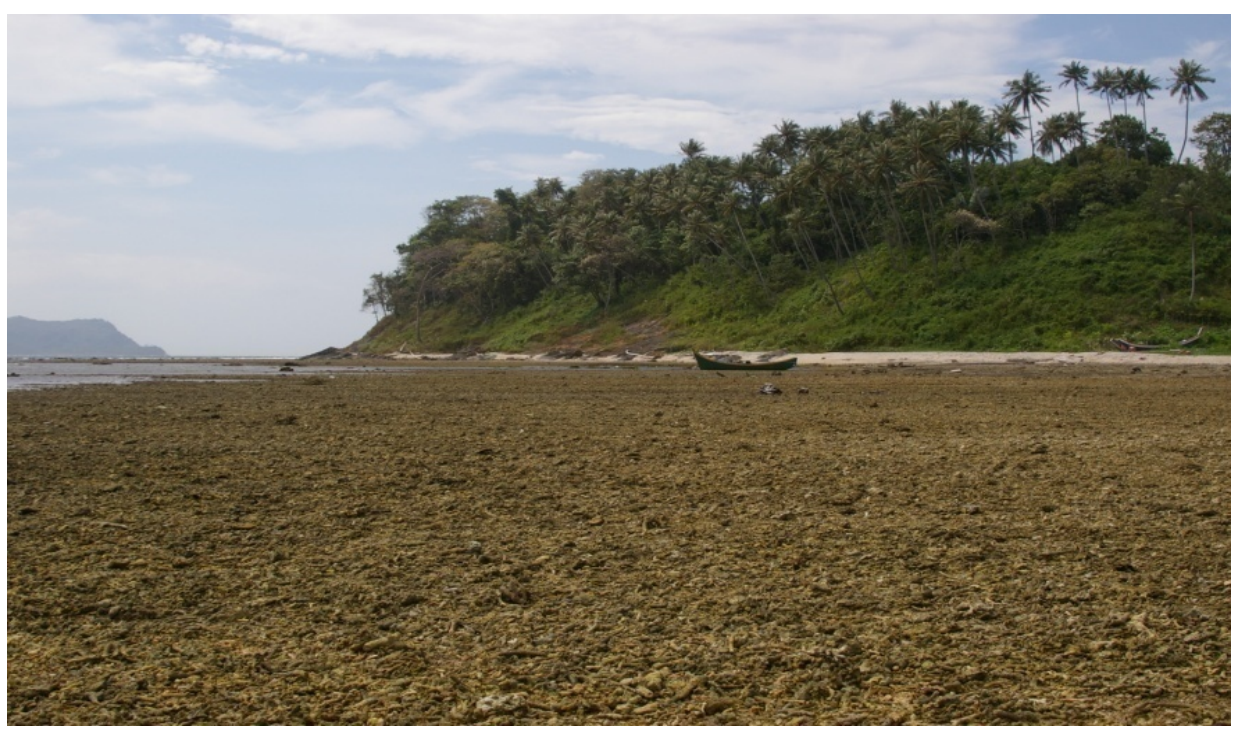

Figure 2. Stretch of reef conditions in the intertidal area (Gampong Paloh) in Pulo Aceh after tsunami (modified from; munthadar, 2008) 


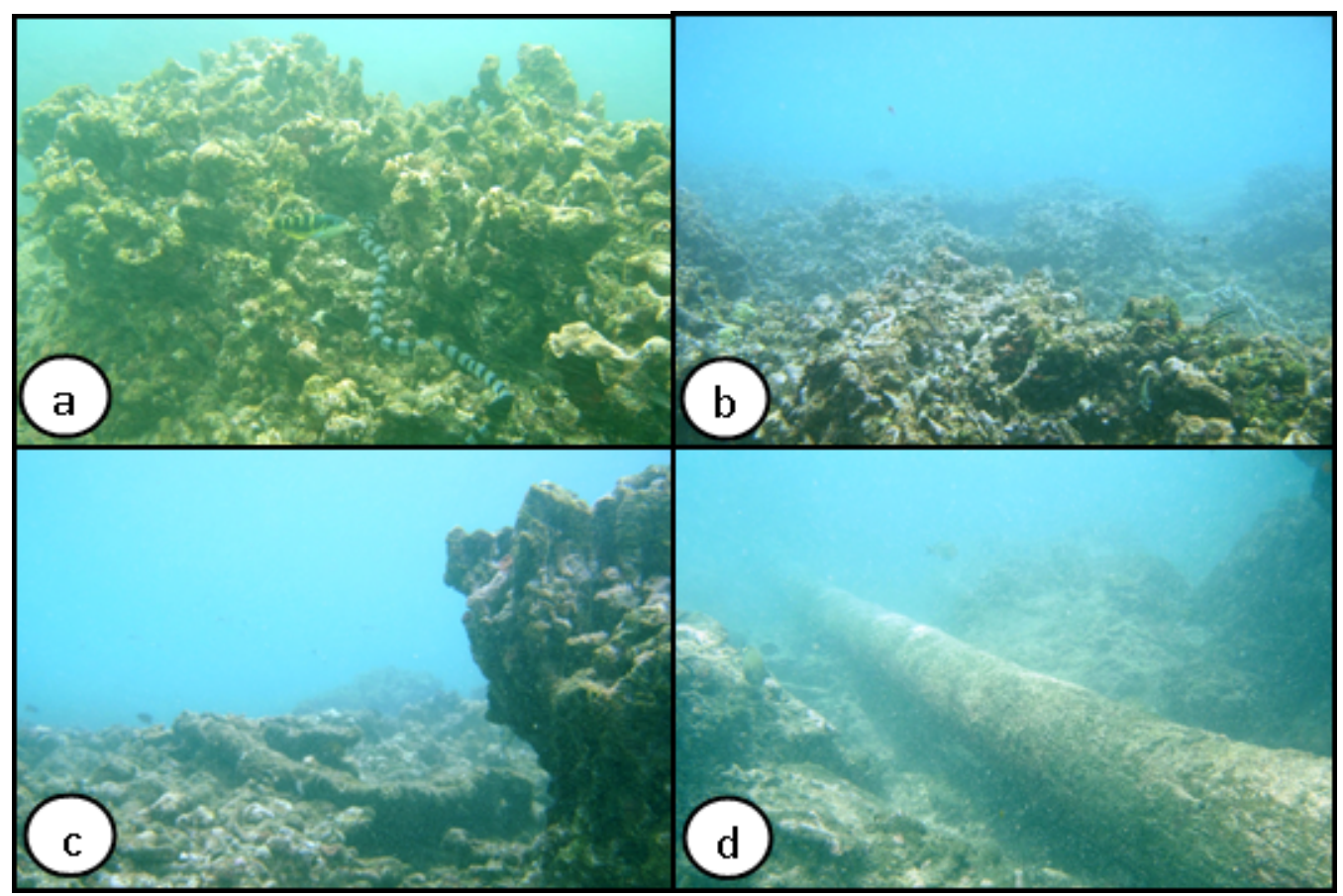

Figure 3. The condition of damaged coral reefs in (a) Kareung Mane (b) Kareung Maja (c) Kareung Pante Demit (d) Kareung Maja

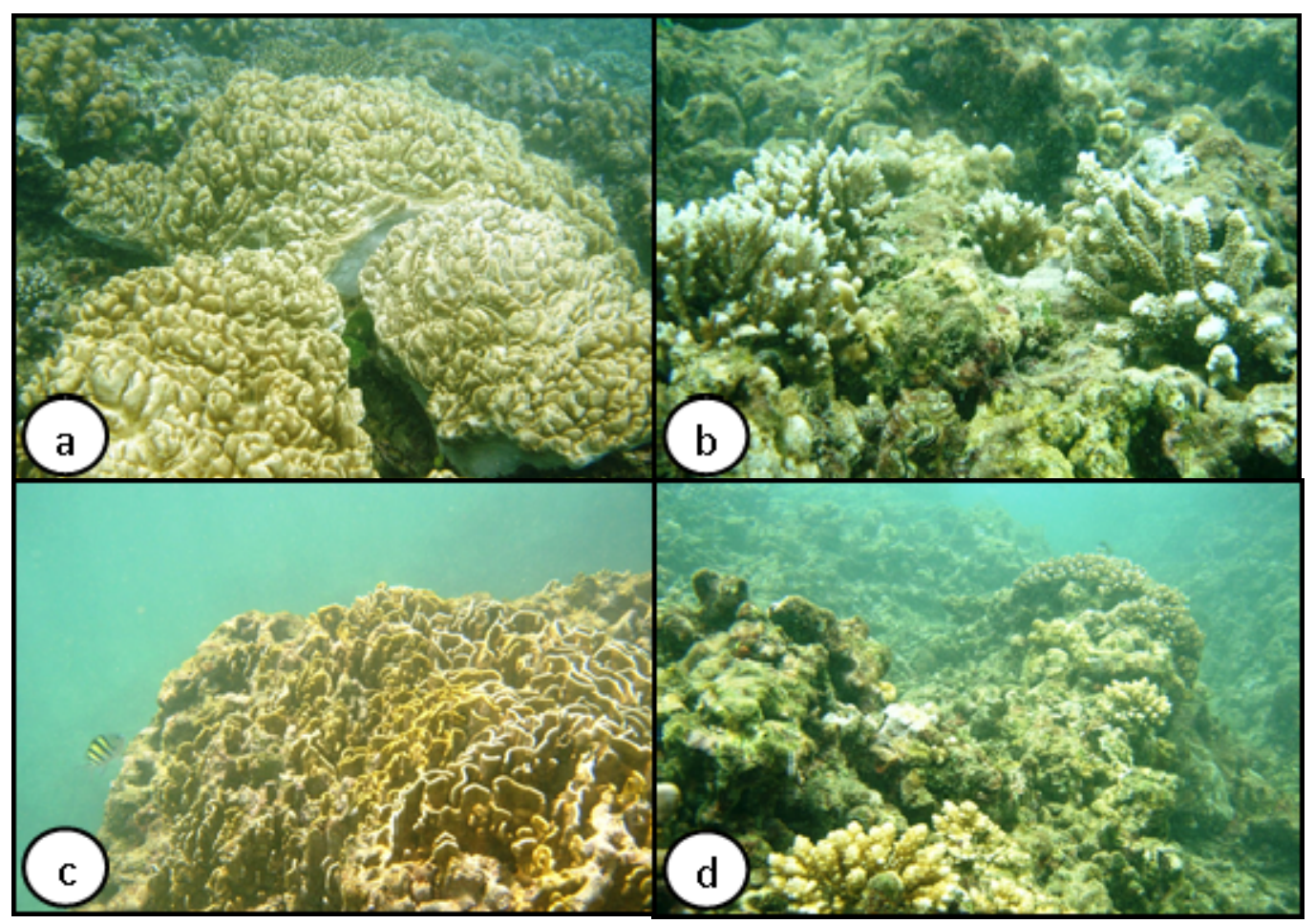

Figure 4. Coral colonies began to grow again in (a) Kareung Maja (b) Kareung Peunateung (c) Kareung Mane (d) Kareung Maja

Recruitment of corals, in term of growth and process requires time and under specific conditions. Recruitment is if MPA can be enforced. MPA zoning practices can provide an opportunity for the ecosystem of the region to develop properly without any interference from humans activities in the areas.

Clustering Zonation MPA is made from field observations and secondary data. The result was a 
thematic layers using GIS layer which consists of physical and social components. The physical components such as coverage, dominance and indices of coral reefs, the pattern and direction of currents, topographical, soil and land use (Figure 5). Social components can be regional profiles, the potential of the region, demographic, and economic and community impact by tsunami.
Overlay of all the layers of physical, social and non-spatial data analysis was conducted into a single layer. A single zoning system was designed to MPA Pulo Aceh, which covers a total area of land and sea with several clustering of zoning as shown in Figure 6.

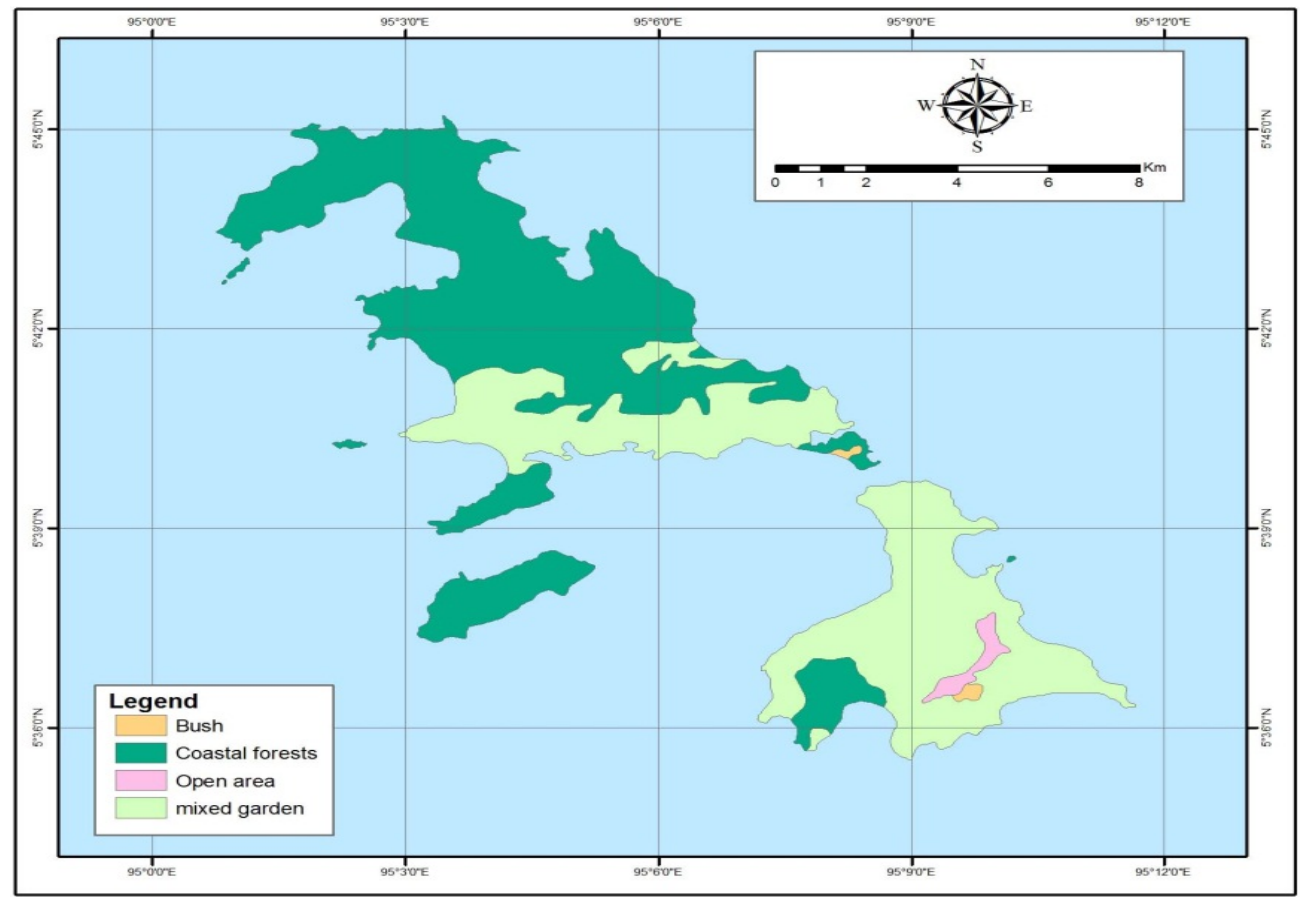

Figure 5. Landuse thematic layer

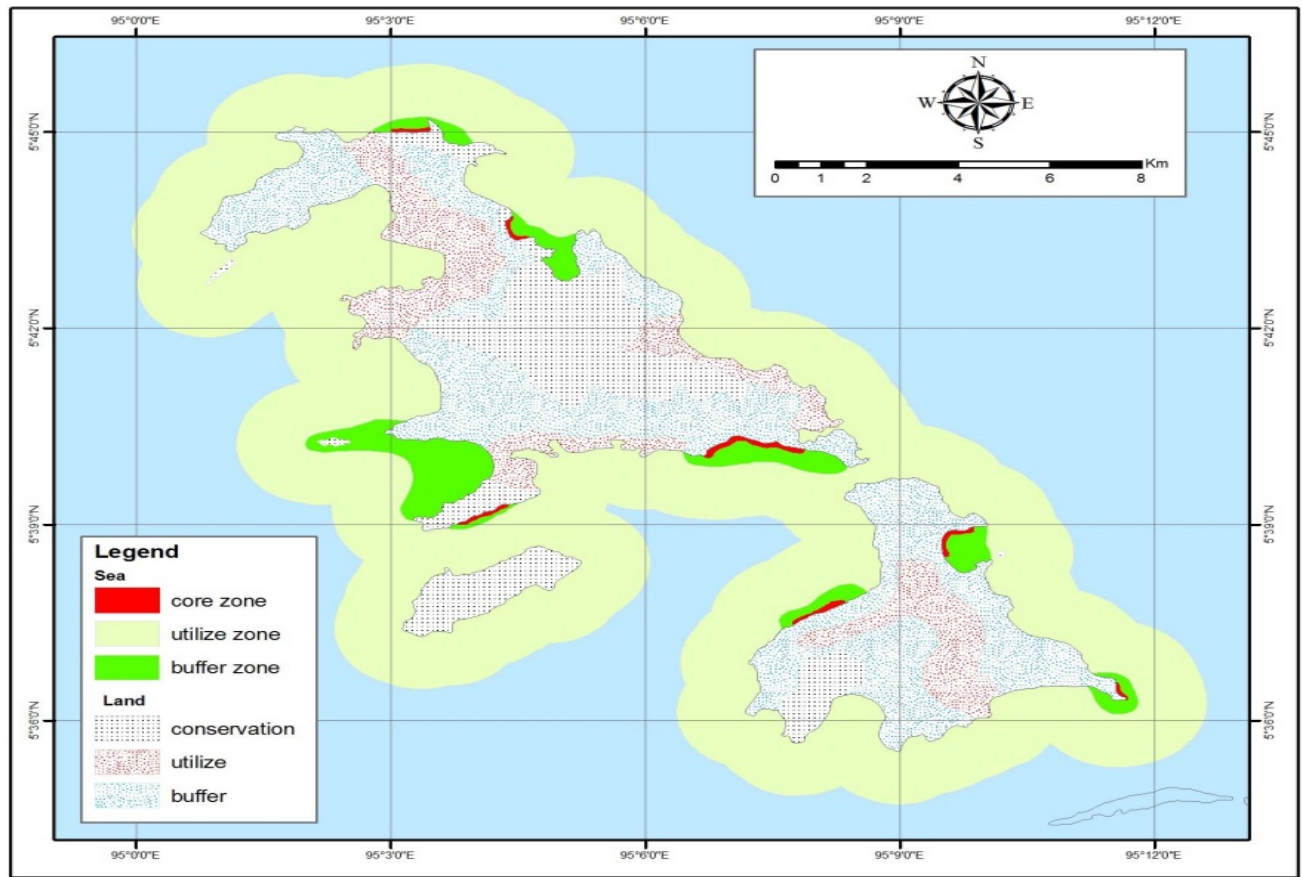

Figure 6. Zonation Clustering in the Marine Protected Areas of Pulo Aceh, Indonesia 
Cluster zonation was made to establish in the marine areas. The class cluster zonation were separated in view sub class as shown in Table 1 :

\begin{tabular}{|l|l|r|r|}
\hline Class & Sub class & Hectare & Percentage \\
\hline \multirow{3}{*}{ Sea } & core zone & 94.14 & 0.38 \\
\cline { 2 - 4 } & utilize zone & $15,144.86$ & 60.67 \\
\cline { 2 - 4 } & buffer zone & $1,038.77$ & 4.16 \\
\hline \multirow{3}{*}{ Land } & conservation & $2,337.14$ & 9.36 \\
\cline { 2 - 4 } & utilize & $2,033.19$ & 8.15 \\
\cline { 2 - 4 } & buffer & $4,312.98$ & 17.28 \\
\hline \multicolumn{2}{|l|}{ Total } & $24,961.09$ & 100.00 \\
\hline
\end{tabular}

The total clustering area MPA of Pulo Aceh was 24,961.09 hectares with two main classes which were sea class and land class area. The sea class areas were divided to three sub class, namely core zone, utilizes zone and buffer zone. The core zone was approximately 94.14 hectare or $0.38 \%$ of sea class total protected areas. The sub class performed in ecotourism zone, traditional use zone, pelagic use zone, special research and training zone. This zone has the largest area to protected about $15,144.86$ hectares or $60.67 \%$ of total MPA area. The buffer zone plotted approximately 1,038.77 hectares or $4: 16 \%$ of total area.

For land class, conservation areas were plotted was about $2,337.14$ or $9.36 \%$ of total protected areas. The utilize zone in land class was 2.033 .19 hectare or $17.28 \%$ of total area. The buffer zone which was a zone to buffered between conservation zone and utilize zone was plotted about $4,312.98$ hectare or $17.28 \%$ of total area. The buffer zone has largest area that planned in land class.

Zoning within the MPA was based on existing ecological data, understanding the principles of ecology and conservation, socio-economic of local communities and culture, and feasibility of implementation. Regulations are prepared for each zone to ensure the continuity of flora and fauna of the region of MPA, ecosystems, and their local communities. Core Zone, Zone with Limited Tourism, Tourism Use Zone and Special Research and Training Zone are zones where all hunting or mining of natural resources and non-biological resources are strictly prohibited.

Harvesting of marine resources is only allowed in the zone of traditional use. Specific rules and sub-zones are designed for the tour. Exit and entry of the ship freely to and through the MPA is only permitted in Pelagic and
Traditional Use Zone. Special permission was required for vessels that will enter into MPA Tourism Zone.

\section{CONCLUSION}

Zonation Clustering in MPA were separated in Core Zone (94, 14 ha, 0.38 \%), Utilized Zone $(15,144.86$ ha, $60.67 \%)$ and Buffer Zone $(1,038.77 \mathrm{ha}, 4.16 \%)$. MPA zoning provide an opportunity for the ecosystem of the region to develop properly without any interference from humans activities in the areas. Need further research for detail zonation with high resolution image satellite.

\section{ACKNOWLEDGEMENTS}

The authors would like to the : Rehabilitation and Reconstruction Bord Aceh-Nias 2007 and Aquaculture Department Malikussaleh University for the support in conducting this research.

\section{REFERENCES}

Barus B., \& U.S Wiradisastra. (1996). Sistem Informasi Geografis, Laboratorium Penginderaan Jauh, jurusan Ilmu Tanah, Fakultas Pertanian, IPB, Bogor, 120 pp.

[BRR] Badan Rehabilitasi dan Rekonstruksi NAD Nias. (2007). Perumusan rencana pengelolaan Marine Protected Areas (MPA) Pulo Aceh Kabupaten Aceh Besar Nanggroe Aceh Darussalam. Badan Rehabilitasi dan Rekostruksi NAD-Nias. Banda Aceh, 226 pp.

[DKP] Departemen Kelautan dan Perikanan Republik Indonesia. (2005). Laporan tim departemen kelautan perikanan terkait dengan inventarisasi dan tugas kemanusiaan bencana alam gempa dan gelombang tsunami di Nanggroe Aceh Darussalam dan Sumatera Utara. Jakarta, 176 pp.

[FAO] Food and Agriculture Organization. (1987). Marine Resources Mapping : an introductory manual. FAO fisheries technical paper. Rome, $104 \mathrm{pp}$.

Jaya, I. N. S. (2002). Aplikasi sistem informasi geografis untuk kehutanan, Penerbit Fakultas Pertanian, Institut Pertanian Bogor, $165 \mathrm{pp}$.

1) Staf Pengajar Fakultas Pertanian Universitas Syiah Kuala

2) Staf Pengajar Fakultas Pertanian Universitas Malikussaleh 
Munthadar, M. (2008). Kajian rehabilitasi sumberdaya dan pengembangan kawasan pesisir pasca tsunami di kecamatan Pulo Aceh kabupaten Aceh Besar. Thesis. Institut Pertanian Bogor, 145 pp.

Prabowo, D., A.T Nugroho, J. Palap., \& H. Ardiansyah. (1999). Modul pengenalan GIS, GPS \& Remote Sensing. Penerbit Forest
Watch Indonesia - Departement GIS. Jakarta. 135 pp.

Prahasta, E. (2009). SIG : Sistem Informasi Geografis Konsep Konsep Dasar (Perspektif Geodesi \& Geomatika). Edisi revisi. Bandung: Penerbit CV. Informatika, 818 pp. 